\title{
PERTIMBANGAN HAKIM TERHADAP TANGGUNGJAWAB TERGUGAT DALAM PEMBERIAN NAFKAH PASCA PUTUSAN CERAI
}

\author{
Erwin Prahara \\ erwin_p@gmail.com \\ Magister Ilmu Hukum Universitas Semarang
}

\begin{abstract}
ABSTRAK
Tujuan penelitian ini membahas tentang pertimbangan majelis hakim terhadap tanggung jawab tergugat dalam memberikan nafkah dalam kajian putusan No. 2257/Pdt.G/2011/PA.Sm) dan kendala serta solusi dalam mengimplementasikan putusan hakim tersebut. Metode pendekatan yuridis normatif, spesifikasi penelitian secara deskriptif data yang diperoleh akan dianalisis secara kualitatif. Hasil penelitian menunjukkan bahwa (1) Pertimbangan Majelis Hakim dalam Memutus Perkara Perdata tentang Cerai Gugat.(Studi Kasus No. 2257/Pdt.G/2011/PA.Sm) bahwa perkara cerai gugat ini tidak dapat diupayakan penyelesaian melalui perdamaian dengan bantuan mediator sebagaimana dikehendaki oleh Pasal 4 Peraturan Mahkamah Agung Republik Indonesia Nomor 1 Tahun 2008 tentang Prosedur Mediasi di Pengadilan kemudian pemeriksaan perkara dimulai dengan membacakan surat gugatan yang berisi alasan gugatan dan Penggugat meminta permohonan kepada Majelis Hakim melalui Ketua Pengadilan Agama Semarang. Tergugat, setelah dipanggil dengan patut sesuai Pasal 122 HIR ternyata tetap tidak hadir. Upaya soliusinya adalah Pemeriksaan dapat dilanjutkan / dilangsungkan tanpa hadirnya tergugat. Tergugat memberikan $1 / 3$ gajinya kepada Penggugat tidak berdasar sehingga permohonan tidak diterima oleh Hakim, upaya solusinya, hendaknya kedua belah pihak memberikan alasan-alasan serta bukti adanya kekeayaan
\end{abstract}

Kata kunci : Pertimbangan Majelis Hakim; cerai gugat; nafkah 
e-ISSN : 2621-4105

\title{
UDGMENT CONSIDERATIONS ON THE RESPONSIBILITIES OF THE ACCUSED FACILITIES IN THE PROVISION OF POST- DECLATED DISTRICT
}

\author{
Erwin Prahara \\ erwin_p@gmail.com \\ Master of Law, University of Semarang
}

\begin{abstract}
This study discusses the consideration of the judges of the defendant's responsibility in providing a living in the study of decision No. 2257 / Pdt.G / 2011 / PA.Sm) and constraints and solutions in implementing the judge's decision. Normative juridical approach, specification of descriptive research data obtained will be analyzed qualitatively. The results showed that (1) Consideration of the judges in the Civil Case Deciding on Divorced Sue. (Case Study No. 2257 / Pdt.G / 2011 / PA.Sm) that contested divorce cases can not be pursued through a peace settlement with the help of mediators as required by Article 4 of the Regulation of the Supreme Court of the Republic of Indonesia Number 1 Year 2008 on Procedures Mediation in court then the case investigation begins by reading the lawsuit on why the lawsuit and the Plaintiff requested an application to the judges by the Chairman of the Religious Court of Semarang. Defendant, having been summoned by inappropriate accordance with Article 122 HIR was still not present, efforts are soliusinya examination can be continued / held without the presence of the defendant. This in turn can lead to the Decision Verstek (without the presence of the Defendant). Petition concerning joint property does not exist, besides the petition that provides third Defendant to the Plaintiff unfounded salary so that the application is not accepted by the judge, the efforts of the solution, the two sides should give the reasons and evidence kekeayaan
\end{abstract}

Keywords: Advisory Panel of Judges; divorced sues ;living 


\section{A. PENDAHULUAN}

Setiap pasangan suami istri senantiasa mendambakan teciptanya rumah tangga yang sakinah, mawaddah, dan waramah. Salah satu faktor penunjang terwujudnya rumah tangga yang sesuai dengan konsep Islam ini adalah harta kekayaan yang merupakan zinatu al-hayat, baik harta yang bergerak maupun tidak, bahkan termasuk didalamnya surat-surat berharga dan hak intelektual. ${ }^{1}$

Salah satu putusan hakim adalah dalam menangani kasus putusnya perkawinan karena perceraian, Perceraian adalah berakhirnya perkawinan yang telah dibina oleh pasangan suami istri yang disebabkan oleh beberapa hal seperti kematian dan atas keputusan keadilan. ${ }^{2}$ Dalam hal ini perceraian dilihat sebagai akhir dari suatu ketidakstabilan perkawinan dimana pasangan suami istri kemudian hidup terpisah dan secara resmi diakui oleh hukum yang berlaku. Putusanya perkawinan karena perceraian dalam Pasal 199 KUH Perdata dapat terjadi karena dua hal, yaitu talak dan gugat cerai. Talak adalah ikrar suami dihadapan Pengadilan Agama yang menjadi salah satu sebab putusnya perkawinan. Cerai gugat adalah perceraian yang disebabkan adanya gugatan dari salah satu pihak, khususnya istri ke pengadilan. ${ }^{3}$ Cerai gugat yang diajukan termuat dalam putusan Pengadilan Agama Semarang, diputuskan oleh seorang hakim Pengadilan Agama Semarang berdasarkan pada ketentuan dalam Undang-Undang No. 1 Tahun 1974 tentang Perkawinan, PP No. 9 Tahun 1975 tentang Pelaksanaan Undang-undang Nomor 1 Tahun 1974 tentang Perkawinan

Salah satu perkara cerai gugat adalah cerai gugat dengan Putusan Pengadilan Agama No. No. 2257/Pdt.G/2011/PA.Sm. Putusan tersebut diambil oleh peneliti karena peneliti ingin mengetahui pertimbangan majelis hakim dalam memutus perkara perdata tentang cerai gugat, akibat hukum dari putusan tersebut dari segi

\footnotetext{
${ }^{1}$ Masrokimin, Perbandingan Antara Hukum Positif Dengan Hukum Islam Mengenai Pembagian Harta Bersama Akibat Perceraian, Jurnal Ius Constituendum Vol 1 No 1, Magister Hukum Universitas Semarang, 2016, Semarang, hlm 2.

2 http://kevinevolution.wordpress.com, perceraian menurut UU No. 1 Tahun 1974

${ }^{3}$ Abdul Karim HS, Perkawinan dalam Konsep Hukum Positif di Indonesia, 2013, http://hukum.online.com diakses 16 November 2016
} 
tanggunghjawab penggugatr dan hambatan-hambatan yang dihadapi majelis hakim dalam memutus perkara perdata tentang cerai gugat.(Studi Kasus No. 2257/Pdt.G/2011/PA.Sm)

Putusan Pengadilan No. 2257/Pdt.G/2011/PA.Sm menyebutkan terjadi gugat cerai yang dilakukan oleh Penggugat (istri) bernama Ahadiah Saleh terhadap Tergugat Arya Anggara (suami), yang disebabkan karena Tergugat tidak bertanggung jawab dan selalu melakukan kekerasan fisik terhadap Penggugat seperti memukul, menampar dan meludahi bahkan Tergugat tega melakukan kekerasan fisik terhadap anak jika tidak menurut.

Pertimbangan hakim dalam putusan cerai gugat tersebut adalah perkara cerai gugat tidak dapat diupayakan penyelesaiannya melalui perdamaian dengan mediator, pertimbangan hakim berdasarkan keterangan saksi-saksi yang saling mendukung satu sama lain dapat dipercaya serta dibuktikan kebenarannya dan dapat menjadi pertimbangan dalam putusan cerai gugat tersebut. Selain itu sejak tahun 2009 antara Penggugat dan Tergugat telah hidup berpisah, dan Tergugat tidak memberi nafkah.

Dalam Undang-Undang Perkawinan tidaklah mudah perceraian itu terjadi tanpa alasan yang dapat diterima. Akan tetapi didalam praktek sehari-hari seorang istri karena alasan-alasan sudah tidak mudah lagi hidup sebagai suami isteri, begitu mudah minta cerai pada suaminya.. ${ }^{4}$

\section{B. PERMASALAHAN}

1. Bagaimana pertimbangan hakim terhadap tanggung jawab tergugat dalam memberikan nafkah dalam kajian putusan nomor 2257/Pdt.G/2011/PA.SM ?

2. Bagaimana kendala dan solusi dalam mengimplementasikan Putusan Hakim No. 2257/Pdt.G/2011/PA.SM terkait tanggungjawab Tergugat dalam memberikan nafkah serta bagaimana tindakan eksekusinya ?

\section{METODE PENELITIAN}

\section{Metode Pendekatan}

Penyusunan tesis ini menggunakan metode pendekatan yuridis normatif 64

${ }^{4}$ Soedharyo Soimin, Hukum Orang dan Keluarga, (Jakarta: Sinar Grafika, 2004), hlm. 
e-ISSN : 2621-4105

\section{Spesifikasi Penelitian}

Spesifikasi penelitian yang dipergunakan adalah deskriptif analitis.

\section{Sumber dan Jenis Data}

Pengumpulan data diperoleh dari sumber data sekunder melalui kepustakaan.

\section{Metode Pengumpulan Data}

Metode pengumpulan data yang digunakan dalam penelitian ini melalui studi pustaka.

\section{Metode Analisis Data}

Metode analisis data dalam penelitian ini dilakukan secara kualitatif, dengan cara mengolah dan menganalisa data-data yang berkaitan dengan permasalahan.,.

\section{PEMBAHASAN}

a. Pertimbangan hakim terhadap tanggung jawab Tergugat dalam memberikan nafkah dalam kajian putusan nomor

\section{7/Pdt.G/2011/PA.SM}

Dalam hal putusan hakim (dictum) yang menyatakan suatu perkawinan batal demi hukum di atur dalam Pasal 70 Kompilasi Hukum Islam, sedangkan perkawinan dapat dibatalkan di atur dalam Pasal 22, 24, 26 dan 27 UndangUndang No.1 Tahun 1974 dan Pasal 71 dan 72 Kompilasi Hukum Islam. Batalnya suatu perkawinan yang terkandung dalam Pasal 28 ayat 1 UU No.1 Tahun 1974 adalah setelah keputusan pengadilan mempunyai kekuatan hukum yang tetap dan berlaku sejak saat diberlangsungkannya perkawinan, begitu pula yang terkandung dalam Pasal 74 ayat 2 Kompilasi Hukum Islam.

Pertimbangan hakim secara filosofis dilaksanakan atas dasar hukum yaitu instruksi MA tersebut didasarkan pada ketentuan Pasal 28 ayat (1) UndangUndang No. 48 Tahun 2009 tentang Kekuasaan Kehakiman, yang menegaskan: "Hakim wajib menggali, mengikuti dan memahami nilai-nilai hukum dan rasa keadilan yang hidup dalam masyarakat". Dalam penjelasannya ditegaskan: "Ketentuan ini dimaksudkan agar putusan hakim sesuai dengan hukum dan rasa 
keadilan masyarakat". Itu berarti kalau ternyata isi undang-undang tidak cukup lengkap atau penerapan undang-undang tersebut berpotensi menimbulkan ketidakadilan yang baru, maka hakim wajib menggali nilai-nilai hukum yang hidup dan berkembang di tengah masyarakat tersebut.

Dasar pertimbangan hakim dalam Pengadilan Agama mengenai kasus dalam penelitian ini didasarkan pula pada Pasal 116 huruf (h) Kompilasi Hukum Islam, dalam Pasal tersebut juga hanyalah sebagai alasan dari alasan untuk melakukan perceraian yaitu adanya perselisihan dan pertengkaran.

Dalam kasus No. 2257/Pdt.G/2011/PA.Sm perceraian terjadi adanya alasan ekonomi dan alasan pertengkaran serta perselisihan, sehingga antara Penggugat dan Tergugat tidak dapat di damaikan kembali.

Pertimbangan fakta sosial dalam kasus tersebut bahwa tindakan Tergugat yang tidak menafkahi Penggugat lebih dari jangka waktu yang ditetapkan yaitu lebih dari 6 (enam) bulan.

Prosedur persidangan dalam Pengadilan Agama Islam merupakan percampuran dari berbagai bentuk dan sifat. Ada yang berbentuk upacara yang sangat formal dan tidak formal dengan cara yang tidak rasional hampir suami sendiri di dalam menguji dan mengkaji kebenaran dari fakta-fakta yang ada. Dan sejalan dengan kualitas para pejabat Pengadilan Agama yang dianggap rendah, prosedur yang berlaku dalam Pengadilan Agama ini dianggap kacau dan rendahan serta serba gelap oleh para ahli hukum sipil, karena tidak mmpunyai Hukum Acara tidak mempunyai landasan-landasan hukum sebagaimana persidangan harus diselenggarakan serta tidak mempunyai kekuasaan untuk menghadirkan saksi-saksi di persidangan.

Dasar pertimbangan hakim dalam memutus perkara perceraian setelah dijalani suatu persidangan yang telah diselenggarakan adalah dengan menggunakan dasar hukum yang terdapat dalam Pasal 38 Undang-Undang No 1 Tahun 1974

Dasar hukum hakim mengabulkan dan memutus perkara perceraiannya antara penggugat dan tergugat disebabkan hubungan keduanya sudah tidak akan bisa didamaikan lagi, terbukti adanya percekcokan dan adu mulut, Melihat dari 
duduk perkara yang ada,keterangan dari tergugat dan penggugat serta dari saksisaksi yang ada,majelis hakim juga sudah mempertimbangkan untuk memutus cerai dengan dasar pasal 39 Ayat 1 dan 2 Undang-Undang Nomor 1 Tahun 1974 tentang Perkawinan, Jo. pasal 19 huruf (f) Peraturan Pemerintah Nomor 9 Tahun 1975, dan pasal 116 huruf (f) Kompilasi Hukum Islam, karena itu gugatan penggugat tentang perceraian dapat dikabulkan.

Hukum acara Peradilan Agama adalah peraturan Hukum yang mengatur bagaimana cara mentaatinya Hukum perdata materiil dengan perantaraan hakim atau cara bagaimana bertindak di muka Pengadilan Agama dan bagaimana cara hakim bertindak agar Hukum itu berjalan sebagaimana mestinya Pasal 54 Undang-Undang Nomor 7 Tahun 1989 tentang Peradilan Agama menyatakan "Hukum acara yang berlaku pada pengadilan dalam lingkungan Peradilan Agama Adalah Hukum Acara Perdata berlaku pada pengadilan dalam lingkungan Peradilan Umum, kecuali yang telah diatur secara khusus dalam undang-undang ini” Dari hasil proses yang telah diuraikan sebagaimana diatas para hakim yang menyidangkan suatu perkara hendaknya menuangkannya dalam bentuk tulisan yang disebut dengan putusan. Karena putusan tersebut merupakan suatu tulisan argumen dengan format yang telah ditentukan Undang-Undang, dengan dibuat putusan tersebut diharapkan dapat menimbulkan keyakinan atas kebenaran peristiwa hukum dan penerapan peraturan perundang-undangan secara tepat dalam perkara yang diadili tersebut.

\section{b. Kendala dan solusi dalam mengimplementasikan Putusan Hakim No.}

\section{7/Pdt.G/2011/PA.SM terkait tanggungjawab Penggugat dalam} memberikan nafkah.

Berdasarkan hasil penelitian penulis dalam Putusan No. 2257/Pdt.G/2011/ PA.Sm, antara lain :

1. Upaya Hakim dalam mendamaikan Penggugat dan Tergugat tidak berhasil, karena pihak Penggugat tetap berkeinginan untuk mengajukan cerai gugat, karena sudah tidak diberii nafkah lebih dari 2 (dua) tahun.

Upaya solusinya : dalam sidang akhirnya permohonan Penggugat untuk mengajukan carai gugat diterima oleh Penggugat. 
2. Ketidakhadiran Tergugat, hal ini merupakan salah satu hambatan yang dihadapi Majelis Hakim dalam memutus perkara cerai gugat, Upaya yang dilakukan oleh PA Semarang adalah dengan membuat surat pemanggilan pada Tergugat. Tergugat, setelah dipanggil dengan patut sesuai Pasal 122 HIR ternyata tetap tidak hadir,

Upaya soliusinya adalah Pemeriksaan dapat dilanjutkan / dilangsungkan tanpa hadirnya tergugat. Hal ini nantinya dapat berujung pada Putusan Verstek (tanpa hadirnya Tergugat).

3. Petitum mengenai harta bersama tidak ada, selain itu petitum agar Tergugat memberikan 1/3 gajinya kepada Penggugat tidak berdasar sehingga permohonan tidak diterima oleh Hakim, upaya solusinya, hendaknya kedua belah pihak memberikan alasan-alasan serrta bukti adanya kekeayaan

Pengajuan hak asuh terhadap anak/anak-anak oleh pihak isteri, biasanya menggunakan ketentuan-ketentuan hukum sebagaimana diatur di dalam KHI sebagai berikut:

\section{Pasal 105 KHI:}

"Dalam hal terjadinya perceraian:

a. Pemeliharaan anak yang belum mumayyiz atau belum berumur 12 tahun adalah hak ibunya;

b. Pemeliharaan anak yang sudah mumayyiz diserahkan kepada anak untuk memilih di antara ayah atau ibunya sebagai pemegang hak pemeliharaannya;

c. Biaya pemeliharaan ditanggung oleh ayahnya."

Selanjutnya disebutkan pula dalam Pasal 156 KHI sebagai berikut:

"Akibat putusnya perkawinan karena perceraian ialah:

a. anak yang belum mummayiz berhak mendapatkan hadhanah dan ibunya,

kecuali bila ibunya telah meninggal dunia, maka kedudukannya digantikan oleh:

1. wanita-wanita dalam garis lurus ke atas dari ibu;

2. ayah;

3. wanita-wanita dalam garis lurus ke atas dari ayah;

4. saudara perempuan dari anak yang bersangkutan;

5. wanita-wanita kerabat sedarah menurut garis samping dari ayah.

b. anak yang sudah mummayiz berhak memilih untuk mendapatkan hadlanah dari ayah atau ibunya;

c. apabila pemegang hadhanah ternyata tidak dapat menjamin keselamatan jasmani dan rohani anak, meskipun biaya nafkah dan hadhanah telah 
dicukupi, maka atas permintaan kerabat yang bersangkutan Pengadilan Agama dapat memindahkan hak hadhanah kepada kerabat lain yang mempunyai hak hadhanah pula;

d. semua biaya hadhanah dan nafkah anak menjadi tanggung jawab ayah menurut kemampuannya, sekurang-kurangnya sampai anak tersebut dewasa dapat mengurus diri sendiri (21 tahun);

e. bilamana terjadi perselisihan mengenai hadhanah dan nafkah anak, Pengadilan Agama memberikan putusannya berdasarkan huruf (a), (b), dan $(d)$;

f. pengadilan dapat pula dengan mengingat kemampuan ayahnya menetapkan jumlah biaya pemeliharaan dan pendidikan anak-anak yang tidak turut padanya."

Akibat perceraian kedua orang tuanya, anak dari Tergugat dan Penggugat secara otomatis akan kekurangan kasih sayang dari orang tuanya dari mereka hidup terpisah (tidak mendapatkan kasih sayang secara utuh). Walaupun kekurangan kasih sayang, anak tersebut harus mendapatkan pemeliharaan, pendidikan sampai dia mampu untuk berdiri sendiri atau dianggap dewasa. Seperti halnya yang tecantum dalam Pasal 41 Undang-Undang Nomor 1 tahun 1974 sebagai berikut;

Akibat putusnya perkawinan karena perceraian yaitu:

a. Baik ibu atau bapak tetap berkewajiban memelihara dan mendidik anakanaknya, semata-mata berdasarkan kepentingan anak; bilamana ada perselisihan mengenai penguasaan anak-anak Pengadilan memberi keputusannya;

b. Bapak yang bertanggung jawab atas semua biaya pemeliharaan dan pendidikan yang diperlukan anak itu: bilamana bapak dalam kenyataan tidak adapat memenuhi kewajiban kewajiban tersebut. Pengadilan dapat menentukan bahwa ibu ikut memikul biaya tersebut.

c. Pengadilan dapat mewajibkan kepada bekas suami untuk memberikan biaya penghidupan dan/atau menentukan sesuatu kewajiban bagi bekas isteri.

Pasal 106 menyatakan bahwa:

a. Ayat 1 : orang tua berkewajiban merawat dan mengembangkan harta anaknya yang belum dewasa atau dibawah pengampuan, dan tidak 
diperbolehkan memindahkan atau menggadaikannya kecuali karena keperluan yang mendesak jika kepentingan dan kemaslahatan anak itu mengehendaki atau suatu kenyataan yang tidak dapat dihindarkan lagi.

b. Ayat 2 : Orang tua bertanggung jawab atas kerugian yang ditimbulkan karena kesalahan dan kelalaian dari kewajiban tersebut pada ayat 1.

Adapun akibat putusnya perkawinan karena cerai gugat menurut Pasal 156 Kompilasi Hukum Islam antara lain sebagai berikut :

1) anak yang belum mumayyiz berhak mendapatkan hadlahan dari ibunya, kecuali bila ibunya sudah meninggal.

2) anak yang sudah mumayyis berhak memilih untuk mendapatkan hadhanah dari ayah atau ibunya.

3) Apabila pemegang hadhanah tidak dapat menjamin keselamatan jasmani dan rohani anak meskipun biaya nafkah telah dicukupi, maka atas permintaan kerabat yang bersangkutan Pengadilan Agama dapat memindahkan hak hadhanah kepada kerabat yang mempunyai hadhanah pula.

4) Semua biaya hadhanah dan nafkah anak menjadi tanggungan ayah menurut kemampuannya, sampai anak tersebut dewasa dan dapat mengurus dirinya sendiri (21 tahun)

Setelah kita mengetahui beberapa akibat perceraian terhadap suami isteri, maka kita akan melihat lebih lanjut akibat-akibat perceraian terhadap anak keturunannya. Setiap perceraian pasti suami isteri dan anak keturunannya yang menderita akibat-akibatnya. Perlu diketahui pula bahwa keluarga dipandang dari segi kepentingan anak-anak merupakan tempat berlindung yang aman, karena anak-anak mendapatkan kasih sayang, perhatian, penghargaan. Tetapi bila dalam keluarga terjadi perceraian maka anak-anak tidak mendapatkan kasih sayang dari kedua orang tuanya. Sehingga mungkin anak-anak itu akan bergaul bebas di luar rumah yang berakibat mudah menmbulkan delikwensi karena kurang mendapat pengawasan dan bimbingan dari kedua orangtuanya.

Sebagian besar pada anak-anak timbulnya delikwensi adalah berasal dari keluarga yang sudah tidak utuh struktur keluarganya. Keluarga yang tidak utuh struktur keluarganya adalah keluarga di mana terdapat ketiadaan salah satu dari orang tuanya baik karena kematian ataupun karena perceraian.

Setelah terjadinya perceraian pemeliharaan anak tetap menjadi tanggung jawab bapak dan ibu. Lebih-lebih seorang bapak mempunyai hak dan kewajiban 
menanggung biaya terhadap anak-anaknya. Apabila anak-anak masih kecil maka ibulah yang lebih berhak mengasuh anak-anak selama dia belum kawin. Karena ibu lebih sayang kepada anak-anaknya, lebih tahu bagaiamana mendidik anakanak, lagi pula ibu lebih mampu dan sabar dalam mengasuh anak-anak dari para ayah. Kemudian mengenai pemeliharaan anak, sesuai dengan Undang-Undang No. 1 Tahun 1974 yaitu :

1) Kedua orang tua wajib memelihara dan mendidik anak-anak mereka sebaikbaiknya

2) Kewajiban memelihara dan mendidik anak, berlaku sampai anak itu kawin atau dapat berdiri sendiri, kewajiban tersebut berlaku meskipun terjadi perceraian antara kedua orang.

3) Anak yang belum mencapai umur 18 tahun (delapan belas tahun) atau belum pernah melangsungkan perkawinan ada di bawah kekuasaan orang tuanya selama mereka tidak dicabut dari kekuasaannya

4) Orang tua mewakili anak, apabila anak melakukan pebuatan hukum di dalam dan di luar pengadilan

\section{E. PENUTUP}

Pertimbangan hakim dalam tanggung jawab tergugat dalam memberikan nafkah dalam kajian putusan nomor 2257/Pdt.G/2011/PA.Sm bahwa perkara cerai gugat ini tidak dapat diupayakan penyelesaian melalui perdamaian dengan bantuan mediator sebagaimana dikehendaki oleh Pasal 4 Peraturan Mahkamah Agung Republik Indonesia Nomor 1 Tahun 2008 tentang Prosedur Mediasi di Pengadilan, dan bahwa Majelis Hakim telah berusaha agar Penggugat berdamai atau rukun kembali dengan Tergugat, akan tetapi tidak berhasil kemudian pemeriksaan perkara dimulai dengan membacakan surat gugatan yang berisi alasan gugatan dan Penggugat meminta permohonan kepada Majelis Hakim melalui Ketua Pengadilan Agama Semarang, untuk bekenaan menetapkan hari sidang, dengan memanggil pihak-pihak yang berperkara serta memeriksa dan mengadili perkara cerai gugat ini dan menjatuhkan putusan. Pertimbangan hakim dalam mengambil putusan Pengadilan Agama No. 2257/Pdt.G/2011/PA.Sm 
berdasar Pasal 14 dan Pasal 53 Undang-Undang No. 48 Tahun 2009. Pertimbangan hakim secara filosofis dilaksanakan atas dasar hukum yaitu instruksi MA. Dalam kasus No. 2257/Pdt.G/2011/PA.Sm perceraian terjadi adanya alasan ekonomi dan alasan pertengkaran serta perselisihan, sehingga antara Penggugat dan Tergugat tidak dapat di damaikan kembali

Kendala dan solusi dalam mengimplementasikan Putusan Hakim No. 2257/Pdt.G/2011/PA.SM terkait tanggungjawab Tergugat dalam memberikan nafkah. Kendala hakim saat mendamaikan Penggugat dan Tergugat tidak berhasil, karena pihak Penggugat tetap berkeinginan untuk mengajukan cerai gugat, karena sudah tidak diberii nafkah lebih dari 2 (dua) tahun. Upaya solusinya : dalam sidang akhirnya permohonan Penggugat untuk mengajukan carai gugat diterima oleh Penggugat. Ketidakhadiran Tergugat, hal ini merupakan salah satu hambatan yang dihadapi Majelis Hakim dalam memutus perkara cerai gugat, Petitum mengenai harta bersama tidak ada, selain itu petitum agar Tergugat memberikan 1/3 gajinya kepada Penggugat tidak berdasar sehingga permohonan tidak diterima oleh Hakim, upaya solusinya, hendaknya kedua belah pihak memberikan alasan-alasan serrta bukti adanya kekayaan

\section{DAFTAR PUSTAKA}

\section{Buku}

Abdul Wahab Khallaf, Ilmu Usul Fiqh, Dina Utama, Semarang :2004

Achmad Ali, Menguak Tabir Hukum (Suatu Kajian Filosofis dan Sosiologis), Jakarta : Gunung Agung, 2002

Ahmad Rifai, Peranan Hukum oleh Hakim Dalam Perspektif Hukum Preogratif, Jakarta, Sinar Grafika, 2012

Ali Mohammad Daud, Hukum Islam dan Peradilan Agama, Raja Grafindo, Jakarta, 2007

Departemen Agama RI, Al Qur'am dan Terjemahannya, Proyek Pembinaan Perguruan Tinggi, Jakarta, 2010

Hilman Hadikusuma, Hukum Perkawinan Indonesia Menurut Perundangan, Hukum Adat, Hukum Agama, Mandar Maju, Bandung, 2009

Koentjaraningrat, Metode Penelitian Sosial dan Hukum, Rajawali, Bandung, 2011

Laila M Rasyid dan Herinawati, Hukum Acara Perdata, Jakarta : Unimal Press, 2015 
Lilik Mulyadi. Kekuasaan Kehakiman. Surabaya: Bina Ilmu. 2007

Mahfud M.D., "Kepastian Hukum Tabrak Keadilan," dalam Fajar Laksono, Ed., Hukum Tak Kunjung Tegak: Tebaran Gagasan Otentik Prof. Dr. Mahfud MD, Bandung: Citra Aditya Bakti, 2007

Moh. Taufik Makaro, Pokok-Pokok Hukum Acara Perdata (Jakarta : Rineka Cipta, 2004

Muhammad Idris Ramulyo, Asas-asas Hukum Islam, Sinar Grafika, Jakarta, 2005

Mukti Arto, Praktek Perkara Perdata pada Pengadilan Agama, cet V, Pustaka Pelajar, Yogyakarta 2004

Ronny Hanitijo Soemitro, Metode Penelitian Hukum dan Jurimetri. Ghalia Indonesia. Jakarta, 2005

Salim HS, Hukum Islam di Indonesia, Jakarta, Sinar Grafika, 2010

Soedharyo Soimin, Hukum Orang dan Keluarga, Jakarta: Sinar Grafika, 2004

Soerjono Soekanto, Pengantar Penelitian Hukum, UI Press. Jakarta, 2012

Soetojo Prawirohamidjojo, Pluralisme dalam Perundang-Undangan Perkawinan di Indonesia, Surabaya : Airlangga University Press, 2006 Surabaya, 2002 , Hukum Orang dan Keluarga, Airlangga University Press,

Subekti,, Pokok-Pokok Hukum Perdata, Intermasa, Jakarta, 2012

Titik Tri Wulan, Perspektiff Perikatan Nikah. Prestasi Pustaka, Jakarta, 2007

Turmudi Hudri, Kunci Rahasia Jodoh, Penebar Plus, Jakarta, 2007

Yahya Harahap, Beberapa Permasalahan Hukum Acara pada Peradilan Agama, alHikmah, Jakarta

\section{Peraturan Perundang-undangan :}

Undang-Undang Dasar 1945

Kitab Undang-Undang Hukum Perdata (KUH Perdata)

Undang-Undang Nomor 1 Tahun 1974 Tentang Perkawinan

Undang-Undang Nomor 48 Tahun 2009 tentang Kekuasaan Kehakiman

PP No. 9 Tahun 1975 tentang Pelaksanaan Undang-undang Nomor 1 Tahun 1974 tentang Perkawinan

\section{Jurnal}

Abdul Karim HS, Perkawinan dalam Konsep Hukum Positif di Indonesia, 2013, http://hukum.online.com diakses 16 November 2016

Achmad Edi Subiyanto, Mendesain Kewenangan Kekuasaan Kehakiman Setelah Perubahan Undang-Undang Dasar 1945, Jurnal Konstitusi Volume 9 Nomor 4 Desember 2012

Elisabeth Nurhaini Butarbutar, Kebebasan Hakim Perdata dalam Penemuan Hukum dan Antinomi dalam Penerapannya, Jurnal Mimbar Hukum Vol. 23 No. 1, Yogyakarta, FH UGM, 2011, hal. 62

Masrokimin, Perbandingan Antara Hukum Positif Dengan Hukum Islam Mengenai Pembagian Harta Bersama Akibat Perceraian, Jurnal Ius Constituendum Vol 1 
e-ISSN : 2621-4105

No 1, Magister Hukum Universitas Semarang, 2016, Semarang.

http://dx.doi.org/10.26623/jic.v1i2.548

\section{Artikel}

http://kevinevolution.wordpress.com, perceraian menurut UU No. 1 Tahun 1974

Kepastian Hukum Kepastian Hukum", diakses darii http://www.surabaya pagi.com /index.php 9bdfd9f9305b81298 tanggal 16 November 2016

R. Benny Riyanto, Kebebasan Hakim Dalam Memutur Perkara Perdata di

Pengadilan Negeri, Jurnal Hukum Yustitia Vol. 74, Surakarta, FH UNS, 2008, hal. 52

Rifyal Ka'bah, Permasalahan Perkawinan, dalam Majalah Varia Peradilan, No 271 Juni, IKAHI, Jakarta, 2008, hal 7 